\author{
Jarosław JAŃCZAK
}

Poznań

\title{
Przesunięcie koncepcyjne w studiach granicznych
}

\section{Wprowadzenie}

D wie dekady następujące po upadku systemu komunistycznego w Europie charakteryzują się rosnącym zainteresowaniem politologów szeregiem problemów badawczych, takich jak transformacja, demokratyzacja, globalizacja czy integracja europejska. W tym samym okresie (i z podobnych powodów) przeżywają swój renesans studia graniczne (border studies). Retrospektywny ogląd ponad dwudziestu lat dynamicznego rozwoju tego obszaru badawczego pozwala na określenie wyraźnych trendów związanych tak z przedmiotem zainteresowania naukowców, jak i dominującymi podejściami teoretycznymi oraz metodologią prowadzenia badań. Przywołane wymiary wiążą się bezpośrednio z procesami politycznymi i społecznymi zachodzącymi w Świecie Zachodnim, przede wszystkim ze wspomnianymi już integracją europejską oraz globalizacją, ale także z przemianą istoty państwa, rozumienia terytorialności i suwerenności.

Celem niniejszego artykułu jest zarysowanie trendów rozwojowych studiów granicznych. Postawiono tezę, iż granica jako przedmiot badań przesuwana jest ze sfery politycznej ku wymiarowi społecznemu, co oznacza odchodzenie od obiektywizacji zjawisk z nią związanych ku podejściom subiektywnym. Jednocześnie można zaobserwować tendencję do wyodrębniania się dyscypliny badawczej, dysponującej (lub pragnącej dysponować) własnym zapleczem teoretycznym i metodologicznym. Próby takie podejmowane są jednak w warunkach, w których studia graniczne nadal poszukują swojej tożsamości.

\section{Renesans studiów granicznych}

Początek lat dziewięćdziesiątych w Europie i Ameryce Północnej naznaczony był nie tylko politycznym, ale także akademickim entuzjazmem związanym $\mathrm{z}$ - jak się wydawało - ostatecznym przezwyciężeniem podziałów wraz z końcem systemu komunistycznego. Emanacją tego podejścia była koncepcja świata bez granic (borderless world) ${ }^{1}$, naiwnie - jak się wkrótce okazało - zakładająca, iż razem z zakończeniem konfliktu ideologicznego nastąpi globalna standaryzacja normatywna i strukturalna według wzorców zachodnich, czego efektem musi być zmiana znaczenia granic państwowych. Demokratyczny i wolny świat powinien gwarantować swobodny przepływ idei, ludzi i towarów, co możliwe byłoby tylko w warunkach szeroko rozumianej otwartości. Szybko okazało się jednak, iż tak praktyka społeczna, jak i sfera polityki państwowej potrzebują granic i muszą posługiwać się granicami, zarówno jako konstruktami prawnymi, jak i społecznymi, kulturowymi, ekonomicznymi,

${ }^{1}$ J. A. Agnew, A World That Knows No Boundaries? The Geopolitics of Globalization and the Myth of a Borderless World, „CIBR Working Papers in Border Studies” 2003, nr 2. 
itd. $\mathrm{Z}$ jednej strony niektóre granice uległy więc erozji, z drugiej, pojawiły się nowe granice o tradycyjnie rozumianych funkcjach.

Przywołane procesy znalazły bardzo szybko odzwierciedlenie w dynamicznym rozwoju akademickich centrów studiów granicznych, ponownie przede wszystkim w Ameryce Północnej i Europie. Amerykańską platformą wymiany poglądów w tym obszarze stało się (powołane wcześniej, bo już w roku 1976) Association of Borderland Studies ${ }^{2}$. W Europie warto wymienić kilka - zazwyczaj uniwersyteckich - centrów, o odmiennych profilach badawczych. International Bourndaries Reseach Unit (IBRU), będący częścią Uniwersytetu w Durham w Wielkiej Brytanii, specjalizuje się od 1989 roku w klasycznym podejściu do kwestii granic, ze znacznym naciskiem na delimitację granic (w tym także morskich) oraz zarządzanie granicami oraz konfliktami granicznymi ${ }^{3}$. Center for International Border Research (CIBR) na Queens Univeristy w Belfaście nastawiony jest natomiast na rozwiązywanie konfliktów związanych z granicami państwowymi, religijnymi, etnicznymi itp. Związane jest to z kontekstem konfliktu w Irlandii Północnej ${ }^{4}$. Department of Border Region Studies ulokowane na Uniwersytecie Południowej Danii stanowi natomiast osadzony w kontekście pogranicza niemicko-duńskiego ośrodek, w którym dominują najnowsze trendy w badaniach granicznych, odniesione do wysokoprzepuszczalnych, ale historycznie obciążonych granic wewnętrznych strefy Schengen ${ }^{5}$. Czasami badania przyjmują formę projektów, jak w przypadku zainicjowanego w roku 2011 na Uniwersytecie Wschodniej Finlandii w Joensu EU Border Regions ${ }^{6}$. Posiada on profil nastawiony na granice zewnętrzne UE, przede wszystkim granicę z Rosja. Podobnie jak The Centre for EU-Russia Studies (CEURUS) estońskiego Uniwersytetu w Tartu ${ }^{7}$. Obydwie inicjatywy koncentrują się z jednej strony na elementach współpracy transgranicznej i zarządzania granicami, z drugiej natomiast generujące impulsy do testowania percepcji granicy i reborderyzacji związanej z rozpadem Związku Radzieckiego, itd. Projekt Phantomgrenzen realizowany od 2011 roku w Marc Bloch Zentrum berlińskiego Uniwersytetu Humboldta analizuje natomiast pozostałości historycznych granic wewnątrz obecnie istniejących państw ${ }^{8}$.

Zaprezentowane ośrodki i projekty graniczne stanowią jedynie niewielki fragment aktywnie działających inicjatyw. Jednakże w aktywnościach większości z nich zaobserwować można odejście od klasycznego podejścia do problematyki granic. Widać to przynajmniej w dwóch wymiarach. Po pierwsze, poziom narodowy jest zbyt ciasny dla opisu fenomenu granic. Po drugie, pogranicze nie jest limitowane do relacji między dwoma państwami. Obydwa te procesy związane są z rolą organizacji ponadnarodowych $\mathrm{w}$ kreowaniu procesów zmieniających pozycję i rolę państwa narodowego, i w efekcie naturę granicy. Dodatkowo globalizacja i lokalizacja przyczynia się do reakcji w zakresie tożsamości lokalnych co nierzadko wpływa na sytuacje na pograniczu, aktywizując ruchy i trendy dłużej (lub nigdy) nieobecne w określonych realiach ${ }^{9}$.

\footnotetext{
${ }^{2}$ Association of Borderland Studies, http://www.absborderlands.org.

${ }^{3}$ International Bourndaries Reseach Unit, http://www.dur.ac.uk/ibru/.

${ }^{4}$ Center for International Border Research, http://www.qub.ac.uk/research-centres/CentreforInternationalBordersResearch/.

${ }^{5}$ Department of Border Region Studies, http://www.sdu.dk/en/Om_SDU/Institutter_centre/I_Graenseforskning.

${ }^{6}$ EU Border Regions, http://www.euborderregions.eu/.

${ }^{7}$ The Centre for EU-Russia Studies, http://ceurus.ut.ee/.

${ }^{8}$ Phantomgrenzen, http://phantomgrenzen.eu/.

${ }^{9}$ V. Kolossov, Theorizing Borders. Border Studies: Changing Perspectives and Theoretical Approaches, „Geopolitics" 2005, vol. 10, s. 612 .
} 


\section{Tendencje rozwojowe studiów granicznych}

W badaniach nad granicami zaobserwować można szereg problemów i podjeść inspirujących badaczy. W poniższym fragmencie zaprezentowane zostaną najpierw przykłady klasycznych inspiracji badawczych granic, a następnie niektóre z widocznych obecnie tendencji. Stanowić będą one ilustrację przesunięcia koncepcyjnego w analizowanym obszarze.

Klasyczne podejście do badania granic bazowało na ich rozumieniu w logice nauk politycznych i stosunków międzynarodowych. Tak więc, o ile granice Europy średniowiecznej oparte były na relacji lojalności w zamian za opiekę (co prowadziło nierzadko do podwójnej zwierzchności i w efekcie efektu nakładania się władzy na szerokich obszarach pogranicznych), o tyle wraz z rewolucją francuską pojawiła się koncepcja granic naturalnych, opartych o elementy topograficzne i krytycznie modyfikujących feudalną mozaikę zapętleń terytorialnych. Podobnie przedstawiała się - wywodząca się z tradycji niemieckiej - koncepcja granic narodowych, opartych o wspólnotę narodową (a więc przede wszystkim językową) ${ }^{10}$. Warto wskazać również na koncepcje związane z siłą polityczną. Granice postrzegane były jako haushoferowskie pola walki biologicznej czy spykemanowskie linie kontaktu terytorialnych struktur władzy $i$ sity ${ }^{11}$. Wkrótce granice stały się także przedmiotem badań ekonomicznych, przede wszystkim w zakresie strategii rozwojowych oraz integracji europejskiej ${ }^{12}$. Nawet specjaliści od turystyki chętnie sięgali po instytucję granicy, zwracając uwagę tak na jej ograniczający charakter w ruchu turystycznym, jak i na potencjał wnoszony do tej branży ${ }^{13}$. Dotyczył on z jednej strony wymiaru komercyjnego (turystyka zakupowa wykorzystująca różne reżimy podatkowe $\mathrm{i}$ handlowe, a w efekcie cenowe i organizacyjne, stanowiące magnes dla konsumentów) ${ }^{14}$. Z drugiej natomiast pokazywał wymiar pozakomercyjny, pozwalający na doświadczanie na relatywnie niewielkim obszarze wielu kultur, języków, atrakcji architektonicznych, itd. Istotną rolę odegrało też eko podejście do relacji granicznych. Zwracano tu uwagę na zagrożenia środowiskowe, tak związane z zanieczyszczeniem powietrza, jak i wód powierzchniowych. Niemożność ich limitowania do przestrzeni wyłącznie państwowej spowodowały wyodrębnienie nieterytorialnego wymiaru zjawiska i niemożności suwerennej nad nim kontroli. Oznaczało to w wymiarze politycznym zmianę postrzegania suwerenności jako wyłącznej i uzmysłowienie sobie konieczności współpracy transgranicznej jako jedynego sposobu radzenia sobie z problemami nierespektujacymi istnienia granic państwowych.

Na postrzeganie granic jako instytucji zwrócił uwagę między innymi David Newman. Jeżeli przyjąć taka perspektywę to powinny one - podobnie do innych instytucji - posiadać zbiór wewnętrznych zasad, które rzqdza ich zachowaniami, wiele z nich staje się samonapędzajacymi i odpornymi na zmiane $e^{15}$. Istotą zarządzania granicami jest więc inkluzja i ekskluzja, co przejawia się w selektywnej przepuszczalności granicy.

\footnotetext{
${ }^{10} \mathrm{~S}$. B. Jones, Boundary Concepts in the Setting of Place and Time, ,Annals of the Association of American Geographers" 1959, vol. 49, issue 3, s. 247-248.

${ }^{11}$ Ibidem, s. 251.

12 J. Anderson, I. Shttleworth, Theorising State Borders in Capitalism: Spatial Fixes Old and New, „CIBR Working Papers in Border Studies” 2004, nr 2; J. Anderson, Theorizing State Borders: Politics/Economics' and Democracy in Capitalism, „Center for International Border Research Working Papers” 2001, nr 1, Belfast.

${ }_{13}$ D. J. Timothy, Political boundaries and tourism: borders as tourist attractions, „Tourism Management” 1995, vol. $16, \mathrm{nr} 7$.

${ }^{14}$ A. Gelbman, D. J. Timothy, Border complexity, tourism and international exclaves, „Annals of Tourism Research" 2011, vol. 38, issue 1 .

15 D. Newman, Theorizing Borders, „Journal of Borderland Studies”, vol. 18, nr 1, s. 3.
} 
Jednocześnie warto zwrócić uwagę na zmieniający się przedmiot zainteresowania badaczy. Początkowo granica postrzegana była głównie w kategoriach prawno międzynarodowych i politologicznych. $Z$ jednej strony więc zwracano uwagę na linię graniczną, jej przebieg, ustalanie, ale także reżimy polityczne i prawne, które oddzielała. Z drugiej ciekawość badaczy przyciagał instytucjonalny charakter granic, wyrażający się przykładowo we współpracy transgranicznej, euroregionach, miastach partnerskich itd.

Wraz ze zmianą reżimów sprawowania kontroli granicznych w wyniku procesu integracji europejskiej (której egzemplifikacją były regulacje Schengen) oraz normalizacją form współpracy transgranicznej, nastąpiło także przesunięcie fokusu badawczego dominującego w studiach granicznych. Granica zaczęła być postrzegana przede wszystkim jako fenomen socjokulturowy i dyskursywny. James Scott zaproponował nawet procesualne rozumienie granicy. W efekcie następuje zmiana z funkcjonalnego ku kognitywnemu i symbolicznemu rozumieniu granicy ${ }^{16}$. Jak ocenia Vladimir Kolossov, uznano, że granice sq skomplikowanymi fenomenami społecznymi, zwiqzanymi z absolutnymi podstawami organizacji społeczeństwa i psychologia ludzkq ${ }^{17}$. Poniżej przedstawione zostaną przykładowe kierunki badań ilustrujące przywołane przesunięcie koncepcyjne.

\section{A. Cross-border governance}

Ciekawym wymiarem studiów granicznych jest zarządzanie transgraniczne (cross-border governance $)^{18}$, tak na poziomie regionów ${ }^{19}$, euroregionó ${ }^{20}$, jak i miast ${ }^{21}$. Kluczowym pytaniem zadawanym przez badaczy w tym obszarze jest kwestia sposobów wspólnego rozwiązywania problemów w przestrzeni publicznej w wymiarze przekraczającym granicę państwową ${ }^{22}$. Wymiar instytucjonalny rozważań uzupełniany jest tutaj rozważaniami nad transgraniczym zaangażowaniem społeczeństwa obywatelskiego w postaci aktywności trzeciego sektora oraz jednostek, wchodzących w interakcje z jednostkami z drugiej strony granicy. Zwraca się tu uwagę na z jednej strony pragmatyzm instytucjonalny jednostek publicznych, które zachęcone środkami europejskim chętnie angażują się w transgraniczne przedsięwzięcia. Ich postawa nierzadko kontrastuje z alienacją społeczną bazy mieszkańców, którzy z dużo mniejszym entuzjazmem realizują ten wymiar współpracy ${ }^{23}$, co obrazuje specyficzną percepcje problematyki współpracy transgranicznej. O ile więc wspólne polityki sektorowe są fenomenem

${ }^{16}$ J. Scott, Mapping Conceptual Change in Thinking European Borders, Call for Papers, Conference Bergamo, Italy, 3-5.07.2013.

${ }_{17}$ V. Kolossov, Theorizing Borders. Border..., op. cit., s. 606.

${ }^{18}$ S. E. Clarke, Spatial Concepts and Cross-Border Governance Strategies: Comparing North American and Northern Europe Experiences, paper presented at the EURA Conference on Urban and Spatial European Policies, Turin, 18-20 April 2002.

${ }^{19}$ T. Pikner, Reorganizing Cross-Border Governance Capacity. The Case of the Helsinki-Tallinn Euregio, „European Urban and Regional Studies” 2008, vol. 15, nr 3.

${ }^{20}$ M. Żurek, Teoria Wspótpracy transgranicznej na przykładzie Euroregionu Pomerania, Instytut Politologii i Europeistyki Uniwersytetu Szczecińskiego, Szczecin 2011.

${ }^{21}$ T. Lunden, European Twin Cities: models, examples and problems of formal and informal co-operation, ,ISIG Quarterly of International Sociology" 2004, nr 3-4.

${ }^{22}$ E. Gualini, Cross-border Governance: Inventing Regions in a Trans-national, Multi-level Polity, ,DISP Working Paper" 2003, nr 152.

23 J. Jańczak, Cross-border governance jako koncepcja wspólnego zarzqdzania miastem podzielonym. Efektywność w warunkach członkostwa w UE, w: Pogranicze polsko-niemieckie po 2004 roku. Nowa jakość sqsiedztwa?, red. J. Jańczak, M. Musiał-Karg, Wydawnictwo Adam Marszałek, Toruń 2009, s. 214-237. 
nierzadkim, o tyle polityka transgraniczna jako instytucjonalnie rozumiana struktura podejmowania wspólnych decyzji w praktyce jest trudna do znalezienia na europejskich granicach, a transgraniczna polity znajduje się w fazie konstruowania w zdecydowanej większości przypadków $^{24}$.

\section{B. Bordering, de-bordering i re-bordering}

Istotnym kierunkiem badawczym wydaje się być percepcja zanikania granic (de-bordering $)^{25}$ i odtwarzania granic (re-bordeing $)^{26}$, nierzadko w nowych formach i za pomocą innych instrumentów, czego manifestacją jest między innymi ponowne lub nowe oznaczanie granic państwowych, etnicznych, historycznych, itd., określane jako redemarkacja (re-demarcating $)^{27}$. Ten proces wpisuje się nie tylko w upadek mitu świata bez granic, ale w warunkach unijnych na wewnętrznych granicach Schengen oznacza proces, gdzie granice i terytorialność istnieją w świadomości mieszkańców dużo silniej niż w państwowo i politycznie determinowanej rzeczywistości.

James Scott proponuje koncepcję bordering jako metodę interpretacji zjawisk związanych z granicznością i sąsiedztwem. Bordering oznacza codzienna konstrukcje granic przez ideologię, mediację kulturowa, dyskursy, instytucje polityczne, postawy i codzienne formy trans nacjonalizmu ${ }^{28}$. Oznacza to $\mathrm{w}$ jego podejściu wielopoziomowymiarowy charakter zjawiska, obejmujący zarówno poziom kontaktów personalnych, rodzinnych, zawodowych, jak i relacji samorządowych w poprzek granicy, ale także kwestie high politics, wyrażających się w politykach państwowych regulujących relacje graniczne. Jak zauważa David Newman, klasyczny bordering bazował na westfalskim założeniu o konieczności wytyczania i kontrolowania granic, co oznaczało wzajemną akceptację dla wyłącznych suwerenności. De-bordering zmienił znaczenie granic w miejsca kontaktu, jednakże o ile my sami chętnie przekraczamy granicę ku innemu, to niekoniecznie chcemy, aby inny przekraczał ją w naszą stronę ${ }^{29}$.

\section{Granice a tożsamość}

Badanie tożsamości transgraniczych i przeszkód w ich powstawaniu lub odtwarzaniu stanowi kolejny widoczny kierunek w badaniach nad granicami ${ }^{30}$. Często są one powiązane $\mathrm{z}$ badaniami historycznymi lub lingwistycznymi ${ }^{31}$. Ten trend wydaje się koncentrować na

\footnotetext{
${ }^{24}$ M. Klatt, H. Herrmann, Half Empty of Half Full? Over 30 years of Regional Cross-Border Cooperation Within the EU: Experiences at the Dutch-German and Danish-German Border, ,Journal of Borderland Studies” 2011, vol. 26 , issue 1 .

${ }^{25}$ J. K. Blatter, Debordering the World of States: Towards a Multi-Level System in Europe and a Multi-Polity System in North America? Insights from Border Regions, „European Journal of International Relations” 2001, vol. 7, nr 2.

${ }^{26}$ H. Nyyssönen, De-Bordering the State-Re-Bordering the Nation: Nation Policy in Hungary, w: De-bordering, Re-bordering and Symbols on the European Boundaries, red. J. Jańczak, Logos Verlag, Berlin 2011.

27 J. Häkli, Re-Demarcating Transnational Space: The Case of Haparanda-Tornio, w: De-bordering, Re-bordering and Symbols on the European Boundaries, red. J. Jańczak, Berlin 2011.

28 J. Scott, Mapping Conceptual Change..., op. cit.

${ }^{29}$ D. Newman, Theorizing Borders..., s. 5-6.

${ }^{30}$ A. Galasińska, Temporal Shifts in Photo-elected Narratives in a Polish Border Town, „Narrative Inquiry” 2003, vol. 13, nr 2.

${ }^{31}$ G. Custred, The linguistic Consequences of Boundaries, Borderlands, and Frontiers, „Journal of Borderland Studies" 2011, vol. 26, issue 3.
} 
procesach odchodzenia od westfalskego rozumienia granicy (boudary) jako linii rozgraniczającej wyłączne suwerenności państwowe o znacznych potencjałach wewnętrznej homogenizacji i standaryzacji. Przechodzi ona ku granicy rozumianej jako frontier ${ }^{32}$, a więc obszar przenikania się wpływów pochodzących z różnych centrów i tworzących de facto odrębną od nich jakość będącą mieszaniną języków, kultur, religii itd. ${ }^{33}$ Jest to więc podejście zakładające znaczącą erozje tradycyjnie rozumianej państwowości, terytorialności i władzy.

\section{Przeskalowanie}

Ciekawa zmiana koncepcyjna związana jest w przypadku studiów granicznych z manipulowaniem skalą analizy (re-scaling) ${ }^{34}$. Występuje ona w dwóch formach, zmniejszania skali (down-scaling) i zwiększania skali (up-scaling). Obydwa zabiegi mają służyć - w zamyśle naukowców je wykorzystujących - do innowacyjnego wykorzystania granicy jako kategorii badawczej w analizie innego fenomenu, najczęściej politologicznego. W praktyce to zazwyczaj proces integracji europejskiej jest obrazowany za pomocą tego zabiegu.

W przypadku zmniejszania skali, w badaniach pojawia się paradygmat laboratorium. Istota podejścia sprowadza się do założenia, iż w przypadku mniejszych jednostek terytorialnych analizy, dużo efektywniej zaobserwować można proces i zjawiska, które w normalnej skali są trudniej obserwowalne. Szczególnie graniczne miasta bliźniacze oraz regiony transgraniczne używane są do opisanego zabiegu ${ }^{35}$. Przyjmuje się więc, iż bliskość przestrzenna i codzienne interakcje tak struktur administracyjnych, jak i mieszkańców pozwalają na bardzo efektywną ocenę przebiegu procesów integracyjnych ${ }^{36}$. Wymienione jednostki stanowią więc laboratoria - wycinki rzeczywistości, w których w sposób kontrolowany można inicjować i obserwować określone procesy. Skala państwowa nie daje takich możliwości, integracja dla wielu (mega)struktur nie jest elementem codziennej praktyki, a raczej odległym i abstrakcyjnym fenomenem. Przyjmuje się, iż to co działa w laboratorium, powinno również działać w realnym świecie.

Inaczej wygląda zwiększanie skali analizy. Tutaj spojrzenie makro przez pryzmat granic ma dostarczyć generalizacji, które niedostępne są w normalnej skali. I tak Wiliam Walters ${ }^{37}$, Christopher Browning czy Pertti Joanniemi ${ }^{38}$ zakładają, iż dla określenia natury procesów integracyjnych i samej Unii Europejskiej należy sprawdzić, jak zorganizowane są jej granice zewnętrzne. Przyjmują, iż to krawędzie mówią najwięcej o wnętrzu, a aplikując do granic unijnych modele limes, colonial frontier, march czy networked (non)boundary. Przyjmuja oni, iż z ich pomocą można zdiagnozować po pierwsze geostrategie Unii wobec sąsiadów

\footnotetext{
${ }^{32}$ L. K. D. Kristof, The Nature of Frontiers and Bourndries, ,Annals of the Association of American Geographers" 1959, vol. 49, issue 3.

${ }^{33}$ U. H. Meinhof, D. Galasinski, Border Discourse: Changing Identities, Changing Nations, Changing Stories in European Border Communities, A 'state of the art' report part 1, 2000.

${ }^{34}$ R. Kaiser, E. Nikiforova, The performativity of scale: the social construction of scale effects in Narva, Estonia, „Environment and Planning D: Society and Space” 2008, vol. 26.

35 A. Gasparini, European Border Towns as Laboratories of Differentiated Integration, „ISIG Quarterly of International Sociology" 1999-2000, nr 4.

${ }^{36}$ H. Schulz, K. Stokłosa, D. Jajeśniak-Quast, Twin Towns on the Border as Laboratories of European Integration, „FIT Discussion Paper” 2002, no. 4.

${ }^{37}$ W. Walters, The Frontiers of the European Union: A Geostrategic Perspective, „Geopolitics” 2004, vol. 9, nr 3.

${ }^{38}$ C. S. Browning, P. Joenniemi, Geostrategies of the European Neighbourhood Policy, „European Journal of International Relations" 2008, vol. 14, nr 3.
} 
wschodnich i południowych, ale także zdefiniować na ile UE wykazuje (semi)państwowe cechy jednostki politycznej o westfalsko zdefiniowanej terytorialności i terytorialnie sprawowanej suwerenności.

\section{E. Granice fantomowe}

Emanacją podejścia socjokulturowego jest kolejny obszar badawczy - granice fantomowe (phantome borders). Przedmiotem zainteresowania są tu pozostałości nieistniejących już granic państwowych w życiu politycznym, ekonomicznym, społecznym itd. obecnych państw. Historyczne granice określające różne wpływy i przynależność państwową poszczególnych regionów służą jako czynnik wyjaśniający różnice pomiędzy nimi. Bada się tu przykładowo znaczne różnice w preferencjach i zachowaniach wyborczych (przykładowo w Polsce liberalny zachód i północ wobec konserwatywnego wschodu i południa), poziomie religijności, rozwoju ekonomicznym itd. Ponownie więc normatywny i kulturowy wymiar procesu wydaje się być istotniejszy niż linia graniczna i relacje między sąsiadującymi państwami.

\section{F. Bezpieczeństwo}

Granica jako limes związana jest z jej rozumieniem przez Rzymian jako obszar[u] gdzie wszystko jest zorganizowane dla ochrony imperium ${ }^{39}$. A istota granicy jest separowanie tego co swoje od tego co inne. W wyniku tego jedna z głównych funkcji granic jest działanie jako bariery, ochraniajacej nas przed nimi ${ }^{40}$. Jednakże wraz z zanikaniem i transformacją tradycyjnych środków służących egzekwowaniu owej podstawowej funkcji granicy (zniesienie kontroli na unijnych granicach wewnętrznych), inne formy inkluzji i ekskluzji stają się bardziej widoczne.

Paradoksalnie, wśród nowych podejść w studiach granicznych wymienia się kwestie bezpieczeństwa. Widać to przede wszystkim w kontekście zagrożeń globalnych po 11 września 2001 roku oraz wraz z dywersyfikacją granic w Unii Europejskiej.

Ataki terrorystyczne w Nowym Jorku, a następnie w Londynie i Madrycie zmieniły postrzeganie granic przez pryzmat kwestii bezpieczeństwa. Dzieje się tak z jednej strony w wyniku rosnących przepływów osób, towarów i kapitałów, co czyni tradycyjną kontrolę trudną lub niemożliwą. Z drugiej strony natomiast zmienia się sama koncepcja bezpieczeństwa, inaczej lokująca kwestie granic i pograniczy w architekturze bezpieczeństwa.

Osobną kwestią pozostają granice zewnętrzne integrujących się przestrzeni politycznych i ekonomicznych. Tu, z uwagi na podnoszenie standardów kontroli, granice wydają się coraz silniej odgrywać podstawową rolę przyporządkowaną im przez porządek westfalski - politycznego i fizycznego separatora. Dodatkowo pogłębiają one procesy alienacji lub w niektórych przypadkach tworząje od podstaw, dzieląc przestrzeń polityczna, ekonomiczna, kulturowa, o znacznym stopniu homogenizacji (jak w przypadku byłej Jugosławii lub Związku Radzieckiego).

Jednocześnie zmiana perspektywy na inną niż (zachodnio)europocentryczna obrazuje wysoką użyteczność podejść klasycznych, co problem bezpieczeństwa granic ilustruje nad wyraz dobrze. Carl Grundy-Warr i Clive Schofield zwracają uwagę na kilka obszarów, gdzie

${ }^{39}$ S. B. Jones, Boundary Concepts in..., op. cit., s. 246.

${ }^{40}$ D. Newman, Theorizing Borders..., op. cit., s. 3. 
studia graniczne wydają się posiadać znaczny stopień istotności z uwagi na kwestie bezpieczeństwa: konflikty etniczne i etniczno-terytorialne, związanych tak z trwającym nadal budowaniem państw narodowych na bazie tworów wieloetnicznych, jak i klasyczne konflikty międzypaństwowe; granice morskie, szczególnie ich delimitacja w kontekście coraz bardziej intensywnej eksploatacji zasobów naturalnych $\mathrm{z}$ dna morskiego ${ }^{41}$.

\section{Ku własnej tożsamości dyscyplinarnej}

Opisane elementy zwrotu koncepcyjnego stały się składową poszukiwania przez studia graniczne własnej tożsamości dyscyplinarnej. Proces ten widoczny jest w trzech wymiarach: oderwaniu od studiów politologicznych, definiowaniu przedmiotu badawczego oraz próbach budowy własnego zaplecza teoretycznego.

Początkowo studia graniczne stanowiły część składową nauk politycznych i stosunków międzynarodowych. Pomimo widocznych inspiracji dyscyplinarnych były one de facto subdyscypliną wspomnianych dziedzin. Jednakże opisywane przesunięcie koncepcyjne spowodowało interdyscyplinaryzację studiów granicznych. Przejawiała się ona nie tylko silniejszą obecnością socjologów, psychologów, kulturoznawców, medioznawców, geografów społecznych i przedstawicieli innych nauk, ale także wniesieniem przez nich własnych instrumentariów teoretycznych i metodologicznych do badań. Multidyscyplinaryzacja jest oczywiście także konsekwencją odejścia od linearnego rozumienia granicy tego obszaru badawczego. W efekcie pojawił się jednak chaos pojęciowy, gdzie określone pojęcia posiadają odmienne znaczenie dla specjalistów z różnych dziedzin ${ }^{42}$.

David Newman postuluje konieczność określenia agendy badawczej dla studiów granicznych, wskazując na kilka obszarów. Po pierwsze jest to demarkacja granic (boundary demarcation), rozumiana nie tylko fizycznie, ale przede wszystkim jako reguły i regulacje, które generują i podtrzymują różnice. Po drugie zarządzanie granicami (boundary management), jako kluczowe dla istniejących i pożądanych interakcji transgranicznych, tak w wymiarze formalnym, jak i nieformalnym. Po trzecie, badanie stref przejściowych (transition zones) i pograniczy (borderlands). Tu znajduje się miejsce dla badań nad regionami i miastami transgranicznymi. Po czwarte, postrzeganie granic (percieving the border), gdzie faktyczne cechy granicy i cechy jej przypisywane często różnią się znacząco i gdzie te drugie determinują znacząco zachowania i postawy aktorów zaangażowanych w relacje (trans)graniczne. Oni to minimalizują lub wyolbrzymiają jej znaczenie i role przez nią odgrywane w codziennym życiu. Po piąte, granice i relacje siły (borders and power relations) jako pokazujące siły upatrujące korzyści w odgranicznieniu i utrzymaniu granic ${ }^{43}$.

Uważa się, że nie tylko wspólna terminologia (a właściwie jej brak) czy precyzyjne określenie szeroko akceptowanej agendy badawczej jest problemem dla studiów granicznych, także nowa interdyscyplinarna teoria granic jest trudna do zbudowania, co nie zmienia faktu, iż próby takie są podejmowane ${ }^{44}$.

${ }^{41}$ C. Grundy-Warr, C. Schofield, Forty Years on: Revisiting Border Studies. Reflections on the Relevance of Classic Approaches and Contemporary Priorities in Boundary Studies, „Geopolitics” 2005, vol. 10, s. 654-659.

${ }^{42}$ D. Newman, Theorizing Borders..., op. cit., s. 9.

${ }^{43}$ Ibidem, s. 10-19.

${ }^{44}$ V. Kolossov, Theorizing Borders. Border..., op. cit., s. 606-607. 
Poszukując modelu teoretycznego dla analizy granic, przykładowo Emmanuel Brunet-Jailly proponuje cztery przenikające się wzajemnie komponenty. Są to siły rynkowe i przepływy handlowe, aktywności polityczne różnych poziomów zarządzania, lokalna kultura transgraniczna, lokalny transgraniczny impuls polityczny ${ }^{45}$.

Pierwsza z perspektyw przywołuje przepływy dóbr, ludzi i inwestycji, które spinają obydwie strony granicy i pogranicza. Druga, związana jest z wielopoziomowym charakterem zarządzania relacjami transgranicznymi i obejmuje z jednej strony różne poziomy struktur państwowych i samorządowych (od władz lokalnych zaczynając, a na centralnych kończąc), $\mathrm{z}$ drugiej natomiast pozapublicznych aktorów zaangażowanych $\mathrm{w}$ transgraniczne procesy. Trzecia dotyczy elementów związanych z poczuciem tożsamości po obu stronach granicy, bazujących także na elementach językowych, etnicznych, religijnych itd. Czwarta dotyczy natomiast aktywności politycznych podejmowanych przez partie polityczne, organizacje pozarządowe oraz jednostki, a przyczyniające się do tworzenia sieci interakcji wyrażających się między innymi w wymiarze instytucjonalnym, symbolicznym ${ }^{46}$, nieformalnym i innych związanych $\mathrm{z}$ transgranicznymi interakcjami ${ }^{47}$.

\section{Zakończenie}

Zaprezentowane rozważania pokazują problem przesunięcia koncepcyjnego w studiach granicznych. Ich renesans po roku 1989 przejawiał się wykorzystywaniem tak podejść klasycznych, jak i poszukiwaniem nowych, uznających granice za konstrukty społeczne o kognitywnym i symbolicznym charakterze. Nastąpiło także intensywne poszukiwanie własnej tożsamości dyscyplinarnej poprzez próbę zdefiniowania własnego przedmiotu badawczego i aparatu teoretycznego.

Przesunięcie koncepcyjne naznaczone jest jednak paradoksem. O ile zwrot w studiach granicznych, którego istotą jest odejście od linearnego i terytorialnego rozumienia granicy ku percepcji granic i kultury granic jest faktem naukowym i empirycznym, o tyle jego aplikowalność jest ograniczona. W przypadku dużej części granic Świata Zachodniego nowe podejście stanowi unaocznienie procesów politycznych i społecznych, które na nich zaszły. Granice wewnętrzne Unii Europejskiej stały się w praktyce granicami administracyjnymi o nieznacznej wadze z punktu widzenia tradycyjnych funkcji państwowych, takich jak obronność, o postulacie wyłącznej suwerenności nie wspominając ${ }^{48}$. Zmiana rozumienia terytorialności oraz ostudzenie konfliktów związanych z granicami spowodowało, iż inne elementy zaczęły dominować tak w realiach granicznych, jak i w dyskursie naukowym.

Jednak w olbrzymiej ilości pozaeuropejskich przypadków realia graniczne przypominają Europę sprzed kilku dekad. W Afryce i Azji procesy państwo i narodotwórcze powodują, iż klasyczne podejścia do badania granic lepiej korespondują z lokalnymi uwarunkowaniami. Podobnie zresztąjak w przypadku niektórych granic w Europie, szczególnie w obszarze poradzieckimi i byłej Jugosławii. Oznacza to relatywnie dużą aplikowalność podejść tradycyj-

\footnotetext{
45 E. Brunet-Jailly, Theorizing Borders: An Interdisciplinary Perspective, „Geopolitics” 2005, vol. 10, s. 645.

46 T. Lundén, Religious Symbols as Boundary Markers in Physical Landscapes. An Aspect of Human Geography, w: De-bordering, Re-bordering and Symbols on the European Boundaries, red. J. Jańczak, Berlin 2011.

${ }^{47}$ E. Brunet-Jailly, Theorizing Borders: An..., op. cit., s. 645.

${ }^{48}$ B. Germond, From Frontier to Boundary and Back Again: The European Union 's Maritime Margins', „European Foreign Affairs Review" 2010, vol. 15, s. 39.
} 
nych w przypadku granic tradycyjnych i dominację elementów zmiany w przypadku post-terytorialnych granic państwowych.

\section{Bibliografia}

Agnew J. A., A World That Knows No Boundaries? The Geopolitics of Globalization and the Myth of a Borderless World, „CIBR Working Papers in Border Studies” 2003, nr 2.

Anderson J., Shttleworth I., Theorising State Borders in Capitalism: Spatial Fixes Old and New, „CIBR Working Papers in Border Studies" 2004, nr 2.

Anderson J., Theorizing State Borders: Politics/Economics' and Democracy in Capitalism, „Center for International Border Research Working Papers" 2001, nr 1, Belfast.

Blatter J. K., Debordering the World of States: Towards a Multi-Level System in Europe and a Multi-Polity System in North America? Insights from Border Regions, „European Journal of International Relations” 2001, vol. 7, nr 2 .

Browning C. S., Joenniemi P., Geostrategies of the European Neighbourhood Policy, „European Journal of International Relations" 2008, vol. 14, nr 3.

Brunet-Jailly E., Theorizing Borders: An Interdisciplinary Perspective, „Geopolitics” 2005, vol. 10.

Clarke S. E., Spatial Concepts and Cross-Border Governance Strategies: Comparing North American and Northern Europe Experiences, paper presented at the EURA Conference on Urban and Spatial European Policies, Turin, 18-20 April 2002.

Custred G., The linguistic Consequences of Boundaries, Borderlands, and Frontiers, „Journal of Borderland Studies" 2011, vol. 26, issue 3

Galasińska A., Temporal Shifts in Photo-elected Narratives in a Polish Border Town, „Narrative Inquiry” 2003, vol. 13, nr 2 .

Gasparini A., European Border Towns as Laboratories of Differentiated Integration, „ISIG Quarterly of International Sociology" 1999-2000, nr 4.

Gelbman A., Timothy D. J., Border complexity, tourism and international exclaves, „Annals of Tourism Research” 2011, vol. 38, issue 1 .

Germond B., From Frontier to Boundary and Back Again: The European Union's Maritime Margins', „European Foreign Affairs Review" 2010, vol. 15.

Grundy-Warr C., Schofield C., Forty Years on: Revisiting Border Studies. Reflections on the Relevance of Classic Approaches and Contemporary Priorities in Boundary Studies, „Geopolitics” 2005, vol. 10.

Gualini E., Cross-border Governance: Inventing Regions in a Trans-national, Multi-level Polity, „DISP Working Paper" 2003, nr 152.

Häkli J., Re-Demarcating Transnational Space: The Case of Haparanda-Tornio, w: De-bordering, Re-bordering and Symbols on the European Boundaries, red. J. Jańczak, Logos Verlag, Berlin 2011.

Jańczak J., Cross-border governance jako koncepcja wspólnego zarzqdzania miastem podzielonym. Efektywność w warunkach członkostwa w UE, w: Pogranicze polsko-niemieckie po 2004 roku. Nowa jakość sqsiedztwa?, red. J. Jańczak, M. Musiał-Karg, Wydawnictwo Adam Marszałek, Toruń 2009.

Jones S. B., Boundary Concepts in the Setting of Place and Time, „Annals of the Association of American Geographers" 1959, vol. 49, issue 3.

Kaiser R., Nikiforova E., The performativity of scale: the social construction of scale effects in Narva, Estonia, „Environment and Planning D: Society and Space” 2008, vol. 26.

Klatt M., Herrmann H., Half Empty of Half Full? Over 30 years of Regional Cross-Border Cooperation Within the EU: Experiences at the Dutch-German and Danish-German Border, „Journal of Borderland Studies” 2011, vol. 26, issue 1.

Kolossov V., Theorizing Borders. Border Studies: Changing Perspectives and Theoretical Approaches, „Geopolitics" 2005, vol. 10.

Kristof L. K. D., The Nature of Frontiers and Bourndries, „Annals of the Association of American Geographers” 1959, vol. 49, issue 3.

Lunden T., European Twin Cities: models, examples and problems of formal and informal co-operation, „ISIG Quarterly of International Sociology" 2004, nr 3-4. 
Lundén T., Religious Symbols as Boundary Markers in Physical Landscapes. An Aspect of Human Geography, w: De-bordering, Re-bordering and Symbols on the European Boundaries, red. J. Jańczak, Logos Verlag, Berlin 2011.

Meinhof U. H., Galasinski D., Border Discourse: Changing Identities, Changing Nations, Changing Stories in European Border Communities, A 'state of the art' report part 1, 2000.

Newman D., Theorizing Borders, „Journal of Borderland Studies”, vol. 18, nr 1.

Nyyssönen H., De-Bordering the State - Re-Bordering the Nation: Nation Policy in Hungary, w: De-bordering, Re-bordering and Symbols on the European Boundaries, red. J. Jańczak, Logos Verlag, Berlin 2011.

Pikner T., Reorganizing Cross-Border Governance Capacity. The Case of the Helsinki-Tallinn Euregio, „European Urban and Regional Studies" 2008, vol. 15, nr 3.

Schulz H., Stokłosa K., Jajeśniak-Quast D., Twin Towns on the Border as Laboratories of European Integration, „FIT Discussion Paper” 2002, no. 4.

Timothy D. J., Political boundaries and tourism: borders as tourist attractions, „Tourism Management” 1995 , vol. $16, \mathrm{nr} 7$.

Walters W., The Frontiers of the European Union: A Geostrategic Perspective, „Geopolitics”2004, vol. 9, nr 3.

Żurek M., Teoria Wspótpracy transgranicznej na przykładzie Euroregionu Pomerania, Instytut Politologii i Europeistyki Uniwersytetu Szczecińskiego, Szczecin 2011.

\section{Conceptual Shift in Border Studies}

\section{Summary}

Dynamic (re)development of the border studies in Europe and North America after the collapse of communism proved both (geo)political relevance of disappearing and reappearing boundaries, as well as academic interest in describing, explaining and categorizing the above-mentioned processes. Thy have been however homogeneous neither in empirical dimension, nor in analytical reflection. What have been observed is growing conceptual shift in border studies. It is manifested in more and more multidisciplinary approach to the field as well as new focus: social practices instead of geopolitical perspective. Consequently border studies look for their own identity and aspirate to be a separate academic discipline. 
